\title{
Faktor-Faktor Yang Mempengaruhi Tingkat Adopsi InovasiDan Kapabilitas Peternak Pada Kelompok Ternak Kambing
}

\author{
Factors Affecting the Innovation Adoption \\ Rate and Livestock Breeders Capability in \\ Goat Farming Group
}

\author{
Anang Febri Prasetyo ${ }^{* 1}$, Nurkolis" ,Ujang Suryadi* \\ *Jurusan Peternakan, Politeknik Negeri Jember \\ Jalan Mastrip PO BOX 164, Jember \\ ${ }^{1}$ anang_fp@yahoo.com
}

\begin{abstract}
The development of livestock sub-sector is one of the strategic choices in supporting the national economy. Technological innovation plays a very big role in efforts to increase productivity and food production, especially livestock. Livestock groups are a good way to apply innovation to breeders. Institutional livestock is expected to be a means to increase technology adoption. This study aims to analyze the factors that affect the adoption of technology in dairy goat breeders. This research was conducted in Lembah Meru, Jember in August-September 2016, using descriptive method of case study. The results showed that internal factors such as age, educational level, farming experience, number of family members, livelihood, income level, motivation, and number of livestock ownership have no significant effect on technology adoption rate. Factors of age, education level, number of family members, and type of livelihood have a positive value on the rate of technology adoption. The capability of breeders in managing innovation shows high yields such as: (1) adaptability with innovation; (2) the ability to refine innovation; (3) the ability of commitment to innovation; (4) the ability to implement innovation; And (5) the ability to manage the available resources.
\end{abstract}

Keywords : Adoption, Innovation, Capability, Farmer, Goat

\section{PENDAHULUAN}

Pembangunan sub sektor peternakan merupakan salah satu pilihan strategis dalam menopang perekonomian nasional. Secara umum kebutuhan bahan pangan asal hewani masih belum tercukupi, terbukti dari banyaknya import produk peternakan.Data statistik peternakan tahun2010 juga memperlihatkan bahwa asupan protein hewanipenduduk Indonesia masih kurang dari 6 g/kapita/hari(Ditjen Peternakan 2010). Konsumsi protein hewani penduduk Indonesia padatahun 2008 rata-rata $5,45 \mathrm{~g} / \mathrm{kapita} / \mathrm{hari}$, terdiri atas 2,4 gdaging dan 3,05 g susu dan telur. Konsumsi berdasarkanproduk asal ternak pada tahun 2008 ratarata 5,93 kgdaging, 6,91 $\mathrm{kg}$ susu, dan $6,37 \mathrm{~kg}$ telur/kapita/tahun(Ditjen Peternakan 2010).Untuk meningkatkan produktivitas dan produksi pangandunia, inovasi teknologi memainkan peranan yang sangatbesar, yaitu sekitar $80 \%$, jauh lebih besar daripada peranperluasan lahan yang hanya $20 \%$ karena sumber dayalahan sudah sangat terbatas (FAO 2009).

Pembangunan peternakan memerlukan sarana dan prasarana sebagai sumber inovasi. Inovasi 
Anang Febri Prasetyo, Nurkolis ,Ujang Suryadi. Faktor-Faktor Yang Mempengaruhi Tingkat Adopsi InovasiDan Kapabilitas Peternak Pada Kelompok Ternak Kambing.

yang dibutuhkan oleh peternak adalah inovasi yang sesuai dengan kebutuhan yang sifatnya cepat. Astrid (1973) yang menyatakan bahwa petani/peternak akan menerima inovasi, jika ia memperoleh harapan dan manfaat serta saluran-saluran komunikasi yang dipergunakan dianggap menguntungkan dirinya maupun kelompoknya. Segala sesuatu ide, cara-cara baru, ataupun obyek yang dioperasikan oleh seseorang sebagai sesuatu yang baru adalah inovasi.

$$
\text { Adopsi adalah keputusanuntuk }
$$

menggunakan sepenuhnya ide baru sebagaicara bertindak yang paling baik. Keputusan inovasimerupakan proses mental, sejak seseorangmengetahui adanya inovasi sampai mengambilkeputusan untuk menerima atau menolaknyakemudian mengukuhkannya (Suprapto danFahrianoor, 2004). Kelompok ternak merupakan cara yang baik untuk menerapkan inovasi bagi peternak. Kelembagaan peternakan diharapkan menjadi sarana untuk meningkatkan adopsi teknologi.Dari uraian latar belakang masalah diatas maka peneliti tertarik untuk meneliti tentang "faktorfaktor yang mempengaruhi tingkat adopsi teknologi dan kapabilitas peternakpada kelompok peternak kambing".

\section{Tujuan Penelitian}

Tujuan penelitian ini untuk menganalisis faktor-faktoryang mempengarui adopsi teknologi dan kapabilitas peternak kambing perah di kelompok ternak lembah meru.

\section{Manfaat Penelitian}

Diharapkan dengan adanya penelitian ini dapat diketahui faktor apa saja yang mempengaruhi adopsi teknologi dan kapabilitas peternak kambing perah di kelompok ternak lembah meru.

\section{METODOLOGI PENELITIAN}

Penelitian ini dilakukan di Kabupaten Jember, pada kelompot Ternak Lembah Meru. Penelitian ini telah dilaksanakan pada bulan Agustus-September 2016. Penetapan lokasi penelitian diambil secara sengaja (purposive) berdasarkan pertimbangan- pertimbangan tertentu (Singarimbun dan Effendi, 1995) yaitu pada kelompok ternak lembah meru, merupakan kelompok kambing perah yang berkembang, dan banyak menerapkan teknologi, diantaranya pengolahan pupuk organik, pemasaran produk peternakan, dan pembuatan produk olahan berbahan susu kambing.

Penelitian ini menggunakan metode diskriptif studi kasus.Nazir (2003) menjelaskan bahwa metode diskriptif adalah suatu metode dalam meneliti suatu kelompok. Data yang diambil dalam penelitian ini dibagi menjadi 2 yaitu: 1) data primer dan, 2) data sekunder. Data hasil penelitian ini dia analisis menggunakan metode diskriptif.

\section{HASIL DAN PEMBAHASAN}

\section{A. Profil Peternak}

TABEL 1. KARAKTERISTIK PETERNAK

\begin{tabular}{|c|c|}
\hline Keterangan & $\begin{array}{l}\text { Persentase } \\
\quad(\%)\end{array}$ \\
\hline Rata rata Usia peternak (th) & $43,5 \pm 5,58$ \\
\hline \multicolumn{2}{|l|}{ Pendidikan } \\
\hline SD & 38,09 \\
\hline SMP & 38,09 \\
\hline SMA & 23,80 \\
\hline Rata-rata PengalamanBeternak (th) & $7,7 \pm 4,88$ \\
\hline $\begin{array}{l}\text { Rata-rata Jumlah anggota keluarga } \\
\text { (org) }\end{array}$ & $4,35 \pm 1,03$ \\
\hline \multicolumn{2}{|l|}{ Mata pencaharian } \\
\hline Petani & 85,71 \\
\hline Pedagang & 4,76 \\
\hline Swasta & 4,76 \\
\hline PNS & 4,76 \\
\hline \multicolumn{2}{|l|}{ Pendapatan } \\
\hline$<$ Rp. 1 Juta/Bulan & 57,14 \\
\hline > Rp. 1-2 Juta/Bulan & 23,80 \\
\hline > Rp. 2 Juta/Bulan & 19,04 \\
\hline \multicolumn{2}{|l|}{ Motivai beternak } \\
\hline Penghasilan Utama & 66,66 \\
\hline Penghasilan sampingan & 33,33 \\
\hline Rata rata kepemilikan ternak (Ekor) & $12 \pm 8,87$ \\
\hline
\end{tabular}

Ket : data terolah

Umur

Hasil penelitian menunjukkan rata rata usai peternak adalah 43,5 $\pm 5,58$, hal ini menunjukkan bahwa usia peternak di kelompok ternak lembah meru tergolong pada usia produktif. Hermawati (2002) menyatakan bahwa usia berkaitan erat dengan 
adopsi inovasi suatu teknologi. Pada usia produktif orang akan lebih muda menerima dan menerapkan ide ide baru dalam segala aspek kehidupan, terutama dalam pemenuhan kebutuhan ekonomi.

\section{Tingkat pendidikan peternak}

Tingkat pendidikan formal merupakan lama waktu seseorang dalam menerima ilmu pengetahuan secara formal. Tingkat pendidikan formal akan mempengaruhi pola berfikir seseorang, semakin tinggi pendidikannya maka akan semakin cepat dalam menangkap dan memahami metode metode baru yang dilihatnnya. Tingkat pendidikan pada kelompok ternak lembah meru masih tergolong rendah yaitu pada tingkat pendidikan SD dan SMP sebanyak $76 \%$.Tingkat pendidikan yang rendah menjadi faktor penghambat kelancaran kegiatan adopsi inovasi.Seperti pendapat yang dikemukakan Soekartawi (1988), bahwa petani yang berpendidikan tinggi relatif lebih cepat melaksanakan adopsi inovasi.

\section{Pengalaman beternak}

Lamanya seseorang dalam menjalankan usaha peternakan maka akan memudahkan dalam mengatasi masalah serta mengambil keputusan. Pengalaman juga sangat menentukan berhasil tidaknya seorang dalam beternak.Soekartawi (1988) menyatakan bahwa kemampuan peternak dalam menjalankan usaha ternaknya dipengaruhi oleh lamanya keterlibatan peternak tersebut dalam menjalankan usaha peternakan. Rata-ata pengalam beternak anggota kelompok ternak lembah meru adalah $7,77 \pm 4.88$.

\section{Pendapatan Peternak}

Pendapatan peternak sebagian besar $(57,2 \%)$ berpenghasilan kurang dari Rp. 1.000.0000,- hal ini menunjukkan bahwa tingkat pendapatan peternak tergolong rendah. Pendapatan beternak yang rendah dapat memotivasi seseorang untuk mencari penghasilan tambahan diantara dengan usaha sampingan. Namun di lain sisi pendapatan yang rendah mengurangi akses seseorang terhadap akses teknologi, sehingga kurang berperan dalam inovasi namun mampu tidak menghambat adopsi teknologi seseorang. Menurut Sefaat (1990) bahwa tingkat pendapatan akan mempengaruhi keputusan petani dalam mengusahakan usaha taninya dan akan mempengaruhi sikap petani dalam mengambil resiko.

\section{Mata pencaharian}

Mata pencaharian peternak sebagian besar adalah petani $(85,7 \%)$. Usaha pertanian umumnya dapat di integrasikan dengan usaha peternakan.Hal ini menyebabkan sebagian usaha ternak terintegrasi dengan usaha pertanian.Namun peternak umumnya kurang menerapkan teknologi dalam usaha peternakannnya karena usaha pertanian umumnya menyita waktu lebih banyak dari pada usaha peternakan.

\section{Motivasi beternak}

Usaha peternakan merupakan usaha sampingan yang dapat di integrasikan dengan usaha pertanian, hal ini disebabkan karena pakan ternak berasal dari limbah pertanian. Motivasi beternak pada kelompok lembah meru adalah sebagai penghasilan utama peternak $(66,6 \%)$ hal ini menunjukkan bahwa usaha peternakan yang dijalankan lebih menguntungkan dibanding dengan usaha pertanian.

\section{Rata-rata kepemilikan ternak}

Kepemilikan ternak akan menentukan besar kecilnya sekala usaha yang dijalankan oleh peternak. rata-rata kepemilikan ternak pada kelompok ternak lembah meru adalah $12 \pm 8.87$ ekor. Hal ini meunjukkan bahwa usaha ternak yang dijalankan merupakan skala usaha yang sedang, umumnya peternak kambing di pedesaan hanya memelihara 4-5 ekor.Banyaknya jumlah ternak yang dimiliki oleh peternak memiliki tujuan yang sesuai keinginan peternak yaitu sebahai mata pencaharian utama.Soekartawi (1988)menambahkan bahwa banyak teknologi baru yang memerlukan skala operasi yang besar dan sumber daya ekonomi yang tinggi untuk keperluan adopsi inovasi, sehingga ukuran skala usaha tani selalu berhubungan positif dengan adopsi inovasi.

\section{B. Faktor faktor yang mempengaruhi tingkat adopsi teknologi}

Faktor-faktor karakteristik internal yang diduga mempengaruhi kapasitas inovasi individu adalah umur, pendidikan formal, pendidikan non formal, pengalaman kerja, pendapatan, dan luas skala usaha (Fatchiya 2010). Faktor-faktor internal dalam penelitian ini seperti usia, tingkat pendidikan, pengalaman beternak, jumlah anggota keluarga, mata pencaharian, tingkat pendapatan, motivasi, dan jumlah kepemilikan ternak tidak ada yang berpengaruh signifikan terhadap tingkat adopsi 
Anang Febri Prasetyo, Nurkolis ,Ujang Suryadi. Faktor-Faktor Yang Mempengaruhi Tingkat Adopsi InovasiDan Kapabilitas Peternak Pada Kelompok Ternak Kambing.

teknologi.hal ini sejalan dengan penelitian sari (2009) menyatakan bahwa tingkat pendidikan, pengalaman beternak, jumlah kepemilikan ternah, dan jumlah anggota keluarga bukan merupakan kategori adopter.
Berdasarkan Tabel 2. Menunjukkan bahwa faktor usia, tingkat pendidikan, jumlah anggota keluarga, dan jenis mata pencaharian memiliki nilai positif terhadap tingkat adopsi teknologi.

TABEL.2 HUBUNGAN FAKTOR INTERNAL DENGAN TINGKAT ADOPSI TEKOLOGI

\begin{tabular}{|c|c|c|c|c|}
\hline No & Variabel & Kofisien Regresi & $\mathrm{T}_{\text {hit }}$ & Signifikansi \\
\hline 1 & Usia & 0,450 & 1,485 & 0,166 \\
\hline 2 & Pendidikan & 0,061 & 0,234 & 0,820 \\
\hline 3 & Pengalaman & $-0,173$ & $-0,751$ & 0,468 \\
\hline 4 & Jumlah anggota keluarga & 0,148 & 0,415 & 0,686 \\
\hline 5 & Mata pencaharian & 0,399 & 1,794 & 0,100 \\
\hline 6 & Pendapatan & $-0,011$ & $-0,041$ & 0,968 \\
\hline 7 & Motivasi & $-0,535$ & $-1,987$ & 0,072 \\
\hline \multirow[t]{4}{*}{8} & Kepemilikan ternak & $-0,019$ & $-0,075$ & 0,942 \\
\hline & Konstanta & 0,681 & 0,510 & \\
\hline & R Square & 0,512 & & \\
\hline & $\mathrm{F}_{\text {hitung }}$ & 1,445 & & \\
\hline
\end{tabular}

Ket : data terolah

C. Kapabilitas Peternak dalam mengelola Indikator kapabilitas petani mengelola inovasi inovasi

Penyebaran inovasi melalui perantaraan mengacu pada lima inti kapabilitas Baser and kelembagaan petani merupakan aktivitas penting dalam mendorong terjadinya kapabilitas petani mengelola inovasi.Kapabilitas peternak dalam mengelola inovasi adalah semua perilaku individu yang diarahkan untuk menghasilkan, Morgan (2008) yang meliputi: (1) kemampuan beradaptasi dengan inovasi; (2) kemampuan menyaring inovasi; (3) kemampuan komitmen terhadap inovasi; (4) kemampuan melaksanakan inovasi; dan (5) kemampuan mengelola sumberdaya memperkenalkan, dan mengaplikasikan hal-hal baru.

yang ada. Hasil penelitian dapat digambarkan seperti TABEL. 3 KAPABILITAS PETERNAK DALAM MENGELOLA INOVASI

\begin{tabular}{llcc}
\hline No & \multicolumn{1}{c}{ Kapabilitas } & Tinggi (\%) & Rendah (\%) \\
\hline 1 & Kemampuan Beradaptasi dengan Inovasi & 90 & 10 \\
2 & Kemampuan Menyaring Teknologi & 81 & 19 \\
3 & Komitmen terhadap Inovasi & 67,5 & 32,5 \\
4 & Kemampan Melaksanakan Inovasi & 55 & 35 \\
5 & Kemampuan mengelola Sumberdaya yang ada & 65 & 35 \\
\hline
\end{tabular}

\section{Ket: Data Terolah}

\section{Kemampuan beradaptasi dengan inovasi}

Salah satu tujuan utama suatu kelompok peternakan adalah sebagai tempat menerapkan inovasi taknologi.Inovasi bertujuan untuk meningkatkan kemampuan peternak dalam usaha peternakanya.Inovasi teknologi dalam bidang peternakan hingga saat ini cukup banyak, sehingga peternak perlu selektif dalam menerapkannya.Kemampuan peternak ber adaptasi dengan inovasi pada kelompok ternak lembah meru sebesar 90\%.Hal ini menunjukkan bahwa peternak, mudah ber adaptasi dengan inovasi yang baru.

\section{Kemampuan menyaring teknologi}

Kemampuan menyaring teknologi adalah kemampuan peternak untuk mengadopsi teknologi yang diperlukan bagi usaha peternakanya.Hasil penelitian yang diperoleh terlihat bahwa anggota kelompok memiliki kemampuan yang tinggi dalam menyaring dan menerapkan teknologi yang dibutuhkan yaitu sebesar $81 \%$. Kemampuan menyaring teknologi berperan penting dalam bagi peternak, hal ini menunjukkan bahwa peternak memiliki prioritas dalam penerapan teknologi tepat guna.

\section{Komitmen terhadap inovasi}

Komitmen menerapkan dan mengembangkan inovasi akan senantiasa membantu kelompok ternak dalam memecahkan tantangan perubahan dalam persaingan usaha.Tanpa adanya inovasi maka usaha peternakan yang dilakukkan 
tidak dapat berkembang.Hasil penelitian menunjukkan bahwa komitmen peternak terhadap inovasi sebesar $67,5 \%$. Hal ini menunjukkan bahwa peternak memiliki motivasi untuk melakukan inovasi.

\section{Kemampuan melaksanakan inovasi}

Peternak yang inovatif akan selalu berupaya menerapkan dan melakukan perbaikan dengan inovasi secara terus menerus. Hasil penelitian ini menunjukkan bahwa sebagian besar peternak telah menerapkan inovasi yaitu sebesar $55 \%$.

\section{Kemampuan Mengelola Sumberdaya}

Pengelolaan sumberdaya merupakan kesanggupan yang dapat membuat sumberdaya menjadi keunggulan bersaing (Riawati 2013).Hasil penelitian menunjukkan bahwa sebanyak $65 \%$ anggota kelompok menyatakan telah memanfaatkan seluruh sumber daya yang ada, hal ini menunjukkan bahwa peternak telah memanfaatkan berbagai media untuk meningkatkan kemampuan peternak itu sendiri.

\section{KESIMPULAN DAN SARAN}

A. Kesimpulan

Hasil penelitian mengarahkan pada kesimpulan bahwa faktor-faktor karakteristik peternak tidak mempengaruhi tingkat adopsi peternak. Secara keseluruhan faktor kapabilitas peternak dalam mengalola inovasi pada kelompok ternak lembah meru tergolong tinggi.

B. Saran

Diharapkan peternak mampu mengoptimalkan kapabilitas yang ada untuk melakukan inovasi teknologi bagi kepentingan kelompok.

\section{DAFTAR PUSTAKA}

[1] Sari, A.I; Syahlani, S.P, dan Hariyadi, F.T. 2009. Karakteristik Kategori Adopter Dalam Adopsi Inovasi Feed Additive Herbal untuk Ayam Pedaging. Buletin Peternakan Vol. 33(3): 196-203, Oktober 2009. Fakultas Peternakan UGM Yogyakarta.

[2] Astrid, S., 1973. Komunikasi Teori dan Praktek (Jilid 1). Cipta. Jakarta.

[3] Ditjen Peternakan. 2010. Statistik Peternakan 2010 Direktorat Jenderal Peternakan, Jakarta.

[4] Fatchiya A. 2010. Pola Pengembangan Kapasitas Pembudidaya Ikan Kolam Air Tawar di Provinsi Jawa Barat. Disertasi. Fakultas Ekologi Manusia, Institut Pertanian Bogor
[5] FAO. 2009. The State of Food and Agriculture. Livestock in the balance. FAO, Rome

[6] Hermawati, Beri. 2002. Peranan Wanita Tani Pada Usaha Tani Sayuran Dalam Kaitannya Dengan Sasaran Penyuluhan Pertanian Di Kecamatan Jambi Selatan Kota Jambi. Skripsi Fakultas Pertanian Universitas Jambi. Jambi.

[7] Nazir, M. 2003. Metodologi Penelitian. Ghalia Indonesia, Jakarta.

[8] Riawati. 2013. Kapabilitas di Era Persaingan Zaman Ini. Staff Core Faculty PPM School of Management. Harian Kontan 7 Agustus 2017. [Diunduh 2014 Mei 25]. Tersedia pada: http://manajemenppm.wordpress.com/2013/07/03/ka pabilitas-di-era-persaingan-zaman-ini/.

[9] Sefaat. 1990. Sistem Pendidikan Orang Dewasa Sebagai Pendekatan Penyuluhan Pertanian. BLLP. Jambi.

[10] Singarimbun dan Effendi . 1995. Metode Penelitian Survei. LP3ES. Jakarta

[11] Suprapto, T. dan Fahrianoor. 2004. Komunikasi Penyuluhan dalam Teori dan Praktek. Arti Bumi Intaran. Yogyakarta 